\title{
Estimation of economic efficiency of integration processes by example of Eurasian economic union
}

\author{
Olga Ergunova \\ Department of Foreign Economic Activity \\ Ural State University of Economics \\ Yekaterinburg, Russia \\ ergunova-olga@yandex.ru
}

\author{
Viktor Blaginin \\ Department of Regional, Municipal Economy \\ Ural State University of Economics \\ Yekaterinburg, Russia \\ geschenke777@mail.ru
}

\begin{abstract}
Modern economy is characterized by significant strengthening of integration processes caused by the deepening of relations between countries, international trade liberalization, scientific and technological progress, development of productive forces and the deepening of international labor division. This results in the formation of regional associations, which are evolving progressively into independent centers of the world economy. The article highlights various aspects of the integration processes in the common economic space effectiveness evaluation. It considers integration processes through the prism of international trade of member States of the Customs Union and the Common economic space, both from a quantitative point of view (dynamics of trade transaction financial volume, the structure of trade exchange) and qualitative point of view (assessment of intra-industry trade). Special attention is paid to the study of the stages of economic integration and the development of the methodology of its economic efficiency evaluation. The authors developed criteria of integration economic efficiency that may serve as a basis for evaluation of the prospects of the further development and implementation of the integration project.
\end{abstract}

Keywords - trade agreement, foreign trade activity, integration, trade association

\section{INTRODUCTION}

At the present stage of the world economy development, the process of globalization is constantly strengthening. Given the ever-increasing interdependence between different countries, the world economy is gradually turning into an integrated system. Globalization is a universal phenomenon that reflects the growing interdependence of states in addressing common problems and also the close relationship between international and national law [2]. At the same time, together with the process of globalization, the opposite process of regionalization of the world economy is gaining momentum. It may even seem that the formation of regional economic groups leads to the fragmentation of the world economy into parts and to further growth of its autonomy. In fact, globalization and regionalization can coexist harmoniously [4]. The formation of integred regional economic groupings, in the authors' view, is not an obstacle to globalization, but rather a catalyst, as a kind of "bricks" for building an absolutely new global economic system.

In scientific literature, the problems of economic integration, including the creation of the interstate economic entities, are widely highlighted. The European theorist, supporter of the theory of dirigisme, J. Tinbergen, was one of the first who gave definitions of integration [11]. The scientist insisted that integration has positive and negative sides. According to the classicists of Economics, such as A. Smith, D. Ricardo [5] international economic integration is the outcome of the labor division in society, between countries and peoples.

In the $1960-1990 \mathrm{~s}$, in Western economic theory two main approaches to the study of integration appeared: a traditional technological approach and a modern (transactional) one [1]. The proponents of the traditional technological approach understand the process of integration, based on its technological aspects. The second approach, modern or transactional, is now becoming more and more widespread [10]. The table below presents the pool of economic integration theories.

TABLE I. THEORIES OF INTERNATIONAL ECONOMIC INTEGRATION

\begin{tabular}{|c|c|c|}
\hline Theory & Proponents & Period \\
\hline Liberal & V. Röpke, J. Rueff & $1950-1960$ \\
\hline Neo-liberal & G. Weiner, B. Balas & $1950-1960$ \\
\hline Structuralism & $\begin{array}{c}\text { G. Myrdal, A. Marshall, C. } \\
\text { Kindleberger }\end{array}$ & $\begin{array}{c}\text { the mid- } \\
1960 \mathrm{~s}\end{array}$ \\
\hline $\begin{array}{c}\text { Neo-Keynesian } \\
\text { economics }\end{array}$ & $\begin{array}{c}\text { R. Cooper, B. F. Massel } \\
\text { the mid- } \\
1970 \mathrm{~s}\end{array}$ \\
\hline Dirigisme & $\begin{array}{c}\text { J. Tinbergen, R. Sanwald, I. } \\
\text { Shtoler }\end{array}$ & $1960-1970$ \\
\hline Functionalism & D. Mitrany, L. Woolf & $1960-1970$ \\
\hline Neofunctionalism & $\begin{array}{c}\text { E. Haas, L. Lindberg, A. } \\
\text { Etzoni }\end{array}$ & $1960-1970$ \\
\hline Regionalism & \multicolumn{2}{|c|}{ Busset } \\
\hline
\end{tabular}

In the modern world economy, integration processes occur at two levels: global and regional. Since the beginning of the 20th century, these processes have accelerated considerably. As a rule, regional initiatives are even wider than global. In this case, speaking about global integration, the authors mean international organizations, in particular the World Trade Organization (WTO), and under regional processes, they mean regional unions or, in other words, regional trade agreements, as WTO calls it. The WTO was established in 1995 and is the 
successor to the General agreement on tariffs and trade. It is an international organization defining the rules of trade at a global level.

\section{RESEARCH METHODS}

The authors propose to evaluate the degree of integration intensity in different regional associations by a combination of several indicators. They divide it into two groups: macroeconomic parameters and indicators of intraregional trade (table 2).

TABLE II. INDICATORS OF INTEGRATION ECONOMIC EFFICIENCY

\begin{tabular}{|c|c|}
\hline Group & Indicator \\
\hline $\begin{array}{c}\text { Macroeconomic } \\
\text { indicators }\end{array}$ & GNP \\
\cline { 2 - 2 } & GNP per capita \\
\hline \multirow{2}{*}{$\begin{array}{c}\text { Indicators of } \\
\text { intra-regional } \\
\text { trade }\end{array}$} & $\begin{array}{c}\text { Proportion of intraregional trade to total foreign trade } \\
\text { turnover of the countries-members of integration }\end{array}$ \\
\cline { 2 - 2 } & Volume of mutual direct foreign investments \\
\cline { 2 - 2 } & GNal trade, exports and import's share of total \\
\hline
\end{tabular}

The world experience shows that the sustainability of integration within regional association is closely dependent on positive economic effect.

\section{RESULTS AND DISCUSSION}

The indicators given above alow us to evaluate the rate of integration economic efficiency by the example of the Eurasian Economic Union.

TABLE III. MACROECONOMIC INDICATORS OF THE DEVELOPMENT OF EEU MEMBER COUNTRIES

\begin{tabular}{|c|c|c|c|c|c|}
\hline Indicator & $\mathbf{2 0 1 1}$ & $\mathbf{2 0 1 2}$ & $\mathbf{2 0 1 3}$ & $\mathbf{2 0 1 4}$ & $\mathbf{2 0 1 5}$ \\
\hline $\begin{array}{c}\text { GNP, USD } \\
\text { trillions }\end{array}$ & 2,21 & 2,36 & 2,45 & 2,29 & 1,57 \\
\hline $\begin{array}{c}\text { GNP per } \\
\text { capita, } \\
\text { USD } \\
\text { trillions }\end{array}$ & 12460,6 & 13263,6 & 13718,9 & 12753,7 & 8723,9 \\
\hline
\end{tabular}

From 2011 to 2013, the growth of aggregate GNP of the countries of the EEU was observed. Since 2014, this indicator has begun declining. Compared to 2011, in 2015, the GNP fell by $29 \%$. This situation can be explained by the conflict in Ukraine with all its consequences, in particular, the fall in oil prices. Concerning GNP per capita, the situation is similar. Compared to 2011, in 2015, it decreased by $30 \%$. To draw a more complete picture, let us consider the indicators of intraregional trade.
TABLE IV. INDICATORS OF INTRAREGIONAL TRADE OF THE EEU MEMBER COUNTRIES

\begin{tabular}{|c|c|c|c|c|}
\hline Indicator & $\mathbf{2 0 1 2}$ & $\mathbf{2 0 1 3}$ & $\mathbf{2 0 1 4}$ & $\mathbf{2 0 1 5}$ \\
\hline $\begin{array}{c}\text { the share of intraregional trade in total } \\
\text { GNP, } \%\end{array}$ & 5,74 & 5,26 & 5,1 & 5,8 \\
\hline $\begin{array}{c}\text { the proportion of intraregional trade to } \\
\text { total foreign trade turnover, \% }\end{array}$ & 12,7 & 12,1 & 11,9 & 13,6 \\
\hline $\begin{array}{c}\text { the volume of mutual direct foreign } \\
\text { investments, USD } \\
\text { billions }\end{array}$ & 27,2 & 24,7 & 25,2 & 23,7 \\
\hline
\end{tabular}

From 2012 to 2015 , sustainable growth or decay of the indicators of intraregional trade of the EEU are not observed. The last reporting year, the share of intraregional trade turnover both in total GNP and total foreign trade turnover increased by $0.06 \%$ and $0.9 \%$, respectively. Also, 2015 is characterized by a decline in the volume of mutual investments, which can be explained in particular by depreciation of previously created assets due to the devaluation of national currencies.

In the authors' view, it is too early to draw conclusions on the effectiveness of the EEU, since its functioning has started in early 2015 which is quite a short period. The Eurasian Economic Union today is the most important integration project in the post-Soviet space of the CIS. Common history and shared economy management experience gives a huge advantage to the Eurasian integration. The Eurasian Union creation is stated as the final target of Eurasian integration. Of course, its establishment is attended with certain difficulties and requires the deep reforms in the member States. One should also take into account that the success of the project depends significantly on the macroeconomic and political situation in and outside integration processes. The achievement of stated goals and the development of integration is possible only under favorable economic and political conditions [3].

Through the formation of integrating relations, the EEU managers strive to achieve the maximal synergetic effect, which is based on comprehensive use of comparative advantages, unifying states in internal and foreign trade. In 2016, the volume of internal trade between the EEU countries amounted to 84, 51 billion USD in United States. Mutual trade dynamics is presented in figure 1 .

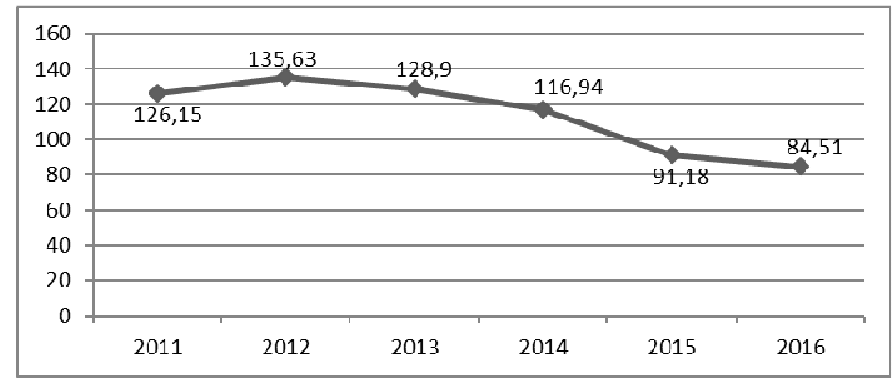

Fig. 1. Dynamics of mutual trade of EEU member countries, USD billions 
Figure 1 shows the decline in the volume of domestic trade between EEU countries over the past 4 years. The dynamics of foreign trade is similar:

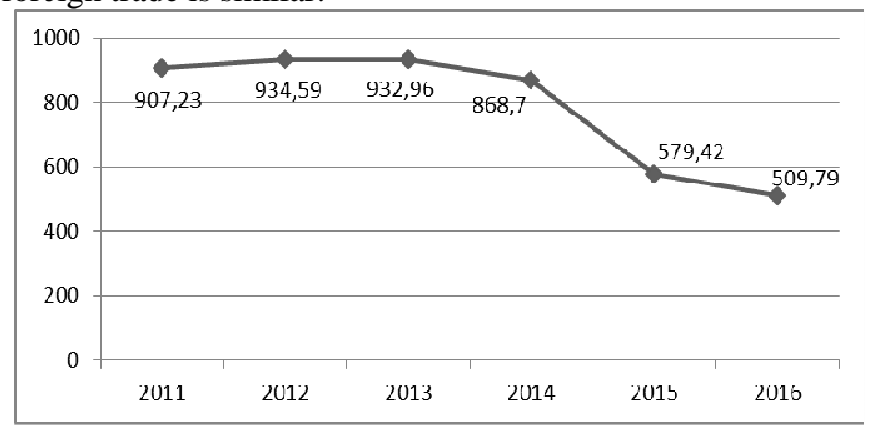

Fig. 2. Dynamics of foreign trade of the EEU, USD billions

The downward trend in trade can be attributed to several main factors:

- Volatility of prices in the world market that influenced the change in average contract prices of the goods of internal trade of the CU and CES.

- Integration processes, when the area of the CU and SES was getting rebuilt into the EEU.

- Volatility of exchange rates of member countries.

- Weakening of the Russian ruble against the US dollar.

- Change of supply networks through the integration and change of the customs regime [6].

Shares of countries-members of the Eurasian Economic Union, both in foreign and mutual trade, are not distributed equally.

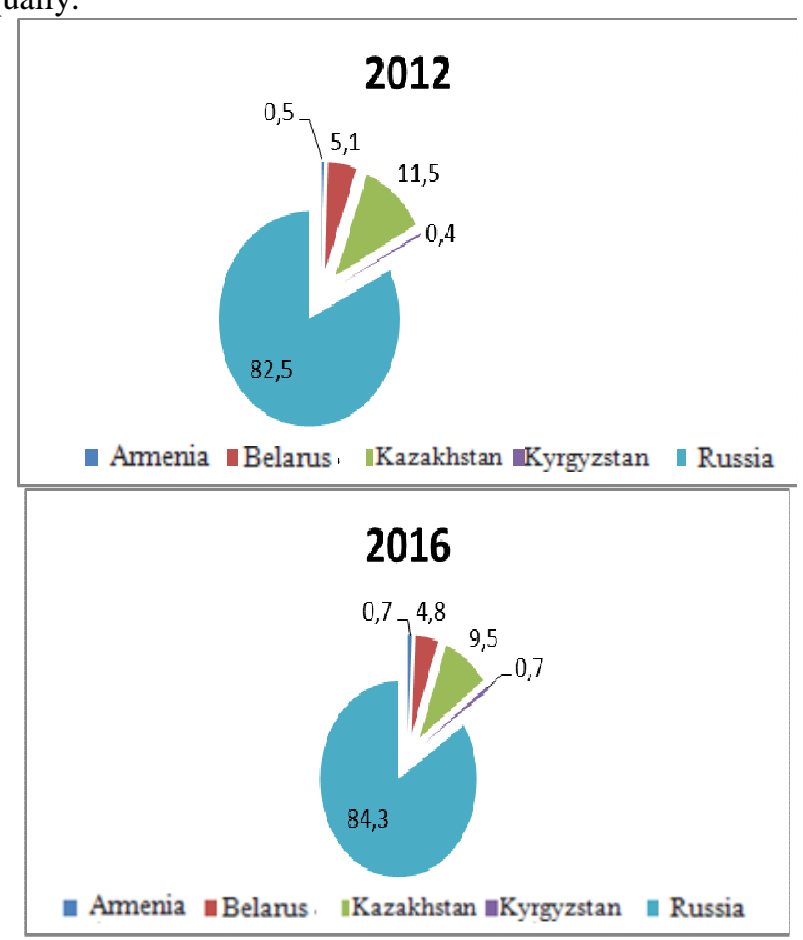

Fig. 3. Shares in the volume of foreign trade of the EEA countries, $\%$
Figure 3 shows the share in the volume of foreign trade of the EEA countries. For 4 years, the overall picture in the distribution of proportions has not changed. The Russian Federation also occupies a leading position with a turnover of $\$ 429.99$ billion, or $84.3 \%$ of the total in 2016 .

The Republic of Kazakhstan is in the second place with a much smaller share of $9.5 \%$; the Republic of Belarus with $4.8 \%$. - in the third place.
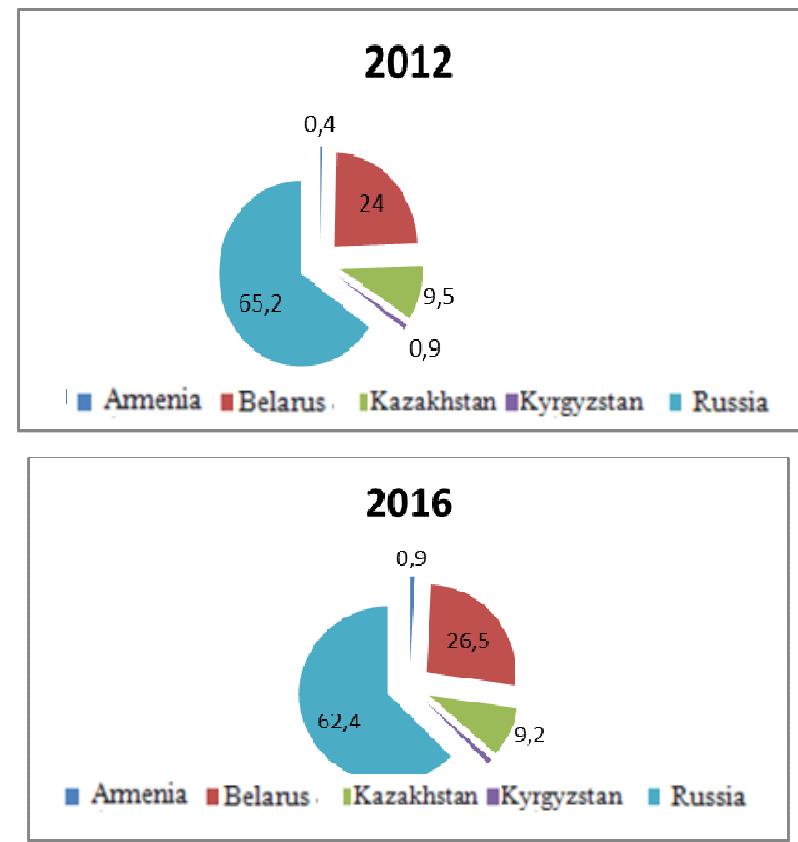

Fig. 4. Shares in the volume of exports of mutual trade in the countries of the Unified Energy System, \%

Figure 4 shows the shares in the volume of exports of the internal trade of the EEA countries in 2012 and 2016. The hierarchy of distribution of shares for the submitted period has not changed. As well as in the external, in the mutual trade in terms of the amount allocated to Russia. Russia exported $62.4 \%$ of the total volume of exports of mutual trade of countries to the countries of the Union in 2016. Russia is followed by Belarus with a share of $26.5 \%$, and Kazakhstan with a share of $9.2 \%$ of the total volume of exports of the mutual trade of the EAEC is in third place [9].

The main picture of the structure of the volume of imports of mutual trade between the EAPC countries from 2012 to 2016 has not changed. But the share of countries in comparison with exports has changed.

In domestic imports, Belarus leads, then Russia goes and Kazakhstan is in third place. In 2016, the exports of the EEA member countries to third countries amounted to 308.4 billion US dollars, while imports, in turn, were at the level of 201.3 billion US dollars. Excess of the value of exported products over imported indicates the trade surplus of the Union [8].

Positive trade balance is, of course, a positive factor in the development of the economy of the EAEC, but for a more accurate conclusion on this account, one must consider the commodity structure of exports and imports. The total picture of exported products has not changed over the past two years. 
In the commodity structure in 2016 , the first place is occupied by mineral products with a share of $60.6 \%$ of the total export volume of the EAEC to third countries. In the second place, there are metals and products from them $-10,5 \%$.

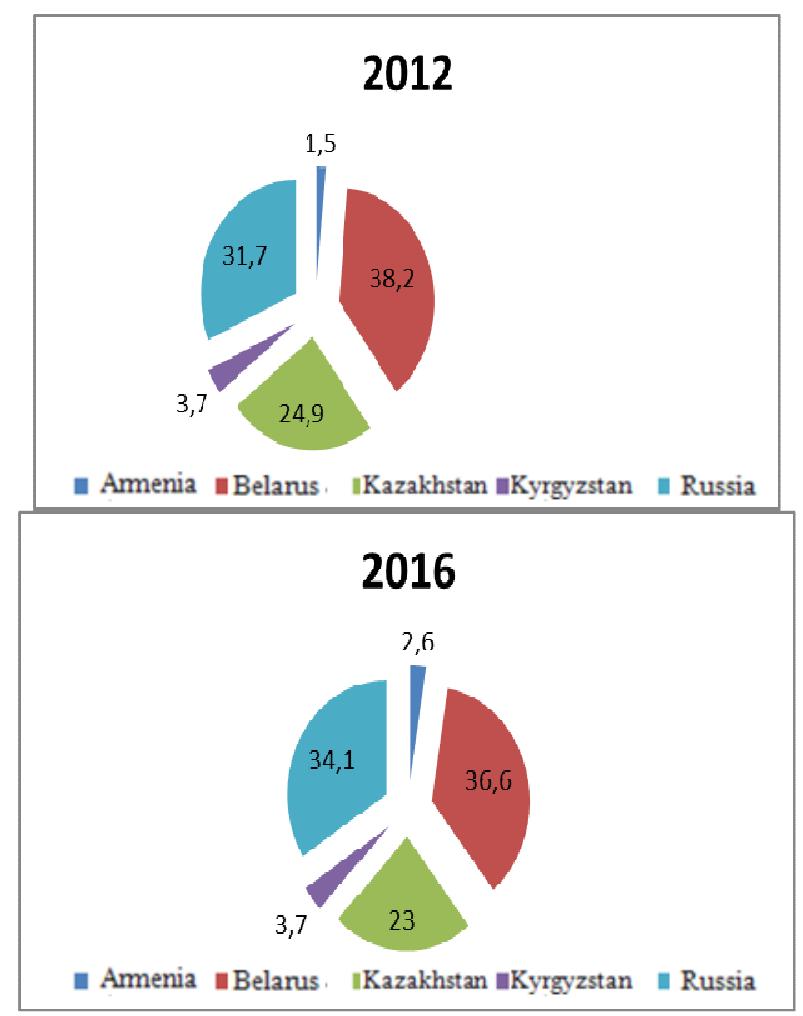

Fig. 5. Shares in the volume of imports of mutual trade in the countries of the Unified Energy System, \%

The overall picture of imported products for two years also is stable. The main imports from the EAC countries are machines, equipment and vehicles. Their share was $43.3 \%$ in 2016. The second place is occupied by products the production of the chemical industry $(18.5 \%)$. Food products and agricultural raw materials are $13.2 \%$ of the total volume of imports of the Eurasian Economic Union to third countries.

Having examined the structure of exports and imports, one can see that the picture is no longer as positive despite the positive trade balance of the EAES. Based on the data, authors can conclude that the countries of the Eurasian Economic Union mainly export raw materials to third countries, and import finished products, which is not good. Countries for the favorable development of their economies should, on the contrary, more produce and sell ready-made products to foreign markets [7].

Let us consider the share of domestic and foreign trade of each member state of the Eurasian Economic Union in the aggregate volume of their trade, using the example of figure 6.

There are no structural changes in the relative weight of domestic and foreign trade in the aggregate trade volume of the countries of the Union for two years of the existence of the EAEC. The share of mutual trade has increased by several percent from Kyrgyzstan, Kazakhstan and Belarus. From the free movement of goods through the territory of the EAEC, the Republic of Belarus wins the most. This is indicated by the volume of its mutual trade with the countries of the Union, which in 2016 amounted to $52.2 \%$ of the total volume of foreign trade.

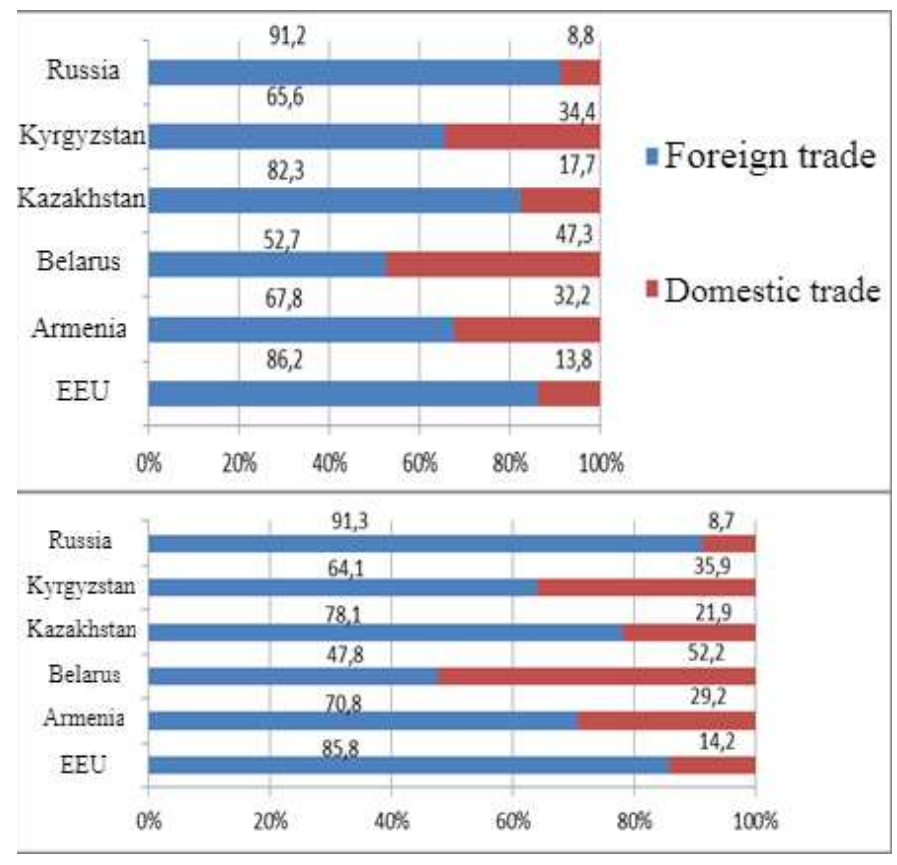

Fig. 6. The share of domestic and foreign trade in the total volume of trade, $\%$

At the same time, the Kyrgyz Republic has this indicator equal to $35.9 \%$, followed by the Republic of Armenia from $29.2 \%$, then the Republic of Kazakhstan $-21.9 \%$, and with the smallest value the Russian Federation - 8.7\%. Russia more than all the countries of the EEA is focused on trade with third countries. The share of foreign trade in 2016 amounted to 91.3\% of the total volume of trade in the Russian Federation. In 2015, the situation with foreign partners in the countries of the EAEC was formed in accordance with Figure 7.

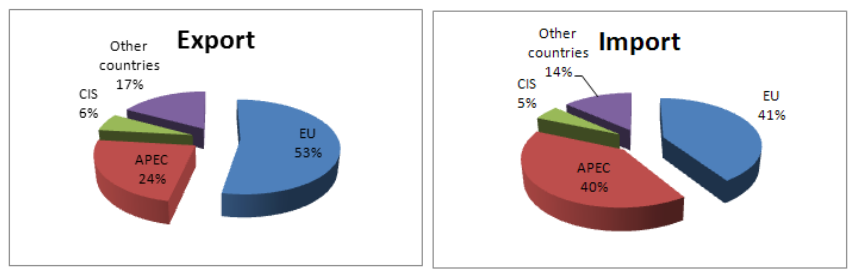

Fig. 7. The share of third countries' groups in the export and import of the EEA in 2015, billion dollars\%

Both in exports and in imports, a greater number of transactions by the participants of the EEA were concluded with the European Union. The EU accounts for $53.2 \%$ of the Union's total exports, while imports account for $40.9 \%$ of the total imports of the EEA. The second indicator is shown by APEC countries $(23.6 \%$ and $40.5 \%$, respectively). The structure of the main partners (Figure 8) explain that the EEMP mainly cooperates with the European countries such as Germany $(8.8 \%$ of the total foreign trade turnover of the Unified Energy System), the Netherlands (8.7\%) and Italy $(7.1 \% \%)[10]$. 


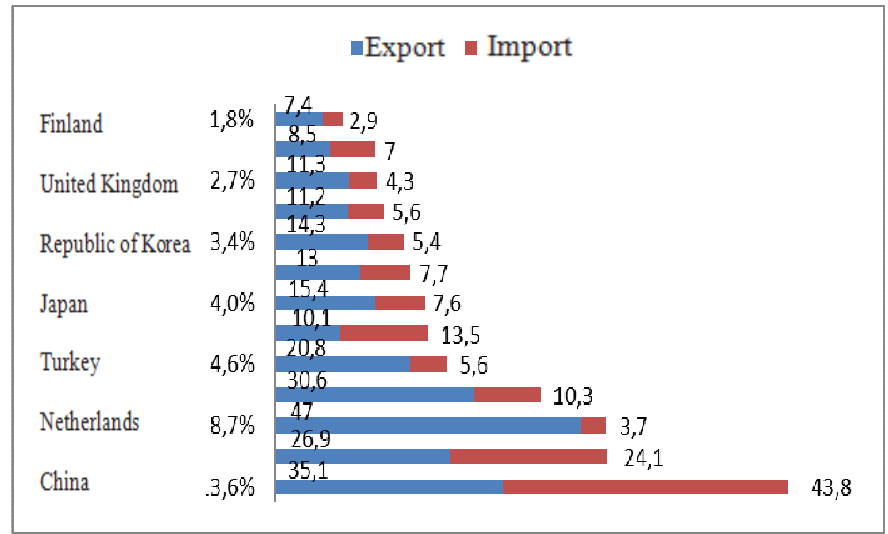

Fig. 8. Partner countries in the external trade of the EAPS in 2015,\%

The largest and most promising trading partner of the EAPS is the People's Republic of China. It accounts for $13.6 \%$ of the total turnover in the Union's foreign trade.

\section{CONCLUSION}

To summarize, the authors would like to highlight the following points. The largest economy in the Eurasian economic Union is the Russian Federation. Its share in foreign trade with third countries is $84.3 \%$ of the total volume, in mutual trade with the countries of the Union $-48.4 \%$. The largest volume of trade occurs with countries of the European Union, but if considering separate countries - with China.

The EEU member exports mineral products (60.6\%), metals and metal products (10.5\% of total exports) to foreign markets. Import is consists of machinery, equipment and vehicles $(43.3 \%)$, chemical products $(18.5 \%)$. Thus, the countries of the EEU mainly export raw materials and import finished goods. While in order to be successful in modern conditions 6 the country should have a developed technological base. Unfortunately, economists cannot say that the integration process, as well as economic efforts of its member countries, is efficient enough, because researchers understand the structure of EEU foreign trade. The economies must be differentiated for the further successful development.

The analysis of the economies of the member countries of the Eurasian Economic Union shows the disparity of the sizes of their economies and territories. The comparison of economic potential of Russia, Kazakhstan, Belarus, Armenia and Kyrgyzstan presents quite a big difference in economic terms.

In this situation, the authors see four ways of further development of the situation:

- Armenia, Belarus, Kyrgyzstan and Kazakhstan support Russia and join the food embargo.

- Member countries of the EEU reject the initial concept of full-fledged Eurasian integration.

- Russian Federation cancels its retaliatory sanctions against third countries.
- Russia does not abandon sanctions policy and continues to pretend that sanctions are respected fully while in fact it has become a formality.

In authors' view, the scenario of a fourth variant will develop further. Although this option is not a solution of the current problem because Russia will continue gaining all the benefits of foreign trade solely, without coordinating trade policy with other members of the EEU, which is totally contrary to the principles of successful integration and can not lead in the long term to the development of the economic efficiency of the Union. The only possible solution is coordinated actions of all member countries on this problem. For the EEU, it is important to be positioned as a united player in the world economy that follows from its ideology [1].

\section{Acknowledgment}

The publication was prepared with the support of the Russian Foundation for Basic Research, research project No.16-33-00010/17 "Forming the identity of migrants from Central Asia and the Russians as a problem of mutual adaptation under the conditions of a Russian megapolis".

\section{References}

[1] S. H. Amr, "Theories of Economic Integration: A Survey of the Economic and Political Literature", International Journal of Economy, Management and Social Sciences, vol. 2(5), pp. 133-155, 2013. Available http://www.waprogramming.com/papers/5157de7c463eb9.70128490.pdf

[2] W.D. Coleman, G.D., Underhill Regionalism and global economic integration: Europe, Asia and the Americas, Routledge, 2012, pp. 32-37.

[3] O. T. Ergunova, V. G. Lizunkov, E. Y. Malushko, V. I. Marchuk, A. Y. Ignatenko, "Forming system of strategic innovation management at high-tech engineering enterprises", IOP Conference Series: Materials Science and Engineering, vol. 177, 2017,Article number 012046.

[4] A. Galiakberov, A. Abdullin, "Theory and practice of regional integration based on the EurAsEC model (Russian point of view)", Journal of Eurasian Studies, vol. 5, pp. 116-121, 2014.

[5] John M. Letiche, "Adam Smith and David Ricardo on Economic Growth”, The Punjab University Economist, vol. 1, No. 2, pp. 7-35, 1960

[6] V. G. Lizunkov, M. G. Minin, E. Y. Malushko, V. E. Medvedev, "Developing economic and managerial competencies of bachelors in mechanical engineering", SHS Web of Conferences, 28, 2016, Article number $01063,1-5$

[7] V.G. Lizunkov, V.I. Marchuk, E.A. Podzorova, "Identification of Criteria, Features of Development and Level of Economic and Managerial Competencies of Bachelors in Mechanical Engineering", Procedia - Social and Behavioral Sciences, 206, 2016, pp.388-393.

[8] M.A. Loshchilova, V.G. Lizunkov, A.V. Zavjyalova, "Professional Training of Mechanical Engineering Bachelors, Based on Network Resources". Procedia - Social and Behavioral Sciences, 206, 2015, pp. 399-405.

[9] E. Malushko, O. Maletina, V. Lizunkov, V. Tsybaneva, "Use of virtual learning system for educating students with disabilities and special needs", SGEM 2016: conference proceedings. BK 1: Psychology And Psychiatry, Sociology And Healthcare, Education Conference Proceedings, Vol I. 2016 [3rd International Multidisciplinary Scientific Conference on Social Sciences and Arts]

[10] D. M. P. McCarthy, International Economic Integration in Historical Perspective. New York: Taylor \& Francis Group, 2007. Available at: http://www.proz-

x.com/stephanlangdon/Library/UR_Core/N_McCarthy.International\%20 Economic\%20Integration\%20in\%20Historical\%20Perspective.pdf 
[11] J. Tinbergen, Equitable Distribution: Definition, Measurement, Feasibility. in: W. KreUe and A.F. Shorrocks (eds.), Personal Income Distribution, Amsterdam/New York/Oxford, pp. 35-50, 1978 